\title{
Research on Application of Evaluation System of Customer Satisfaction with Service Encounter of Express Enterprises
}

\author{
Yong LUO \\ School of Management \\ Wuhan University of Science and Technology \\ Wuhan, China \\ E-mail: luorenyong@foxmail.com
}

Xin MEI

School of Management

Wuhan University of Science and Technology

Wuhan, China

E-mail: 40297270@qq.com

\author{
Yun-Mei LI \\ School of Management \\ Wuhan University of Science and Technology \\ Wuhan, China \\ E-mail: lymwust@163.com
}

\begin{abstract}
The low customer satisfaction and higher complaint rate of express service have become obstacles to the development of many express enterprises. Thus, this paper is intended to focus on customer satisfaction with express services, in particular on the evaluation of customer satisfaction with express service encounter in accordance with the theory of service contract. Specifically, it is planned to summarize the measurement indicators of express service contract and establish an evaluation system of customer satisfaction with express service encounter in combination with the existing literatures and expert opinions. Lastly, suggestions are put forward on how to improve customer satisfaction with services of express enterprises from the perspective of service encounter in accordance with the research conclusions.
\end{abstract}

Keywords-Express service; Service encounter; Customer satisfaction

\section{INTRODUCTION}

With the progressive development of the express industry, customers' logistics needs start presenting the characteristics of difference, diversification and variability. Hence, express enterprises need to improve their service quality and customer satisfaction, and constantly create and develop customer value, so as to keep pace with the rapid development of the market and win a place in the fierce competition. Express enterprises can improve their service quality and service ability in various ways, but the efforts of express enterprises to improve products and services perceivable to customers are relatively limited. Thus, what factors will influence customer satisfaction with services of express enterprises, and how to evaluate customer satisfaction from the perspective of these factors are worthy to be discussed.

The concept of service encounter was first put forward by Norman in the 1980s, who pointed out that service encounter had a huge effect on customers' perception, and customers formed the final feeling and evaluation via service encounter. Since then, theories related to service encounter have been being developed, and the connotations thereof also have become increasingly complete. Batero (2013) pointed out that service encounter referred to interactions between staff and customers, between environmental atmosphere and customers, and between physical products and customers [1]. Qomack (2014) considered the intangible techniques, physical objects and service personnel in the service production system all were in the scope of service encounter. Researches show that the connotation of service encounter had developed from physical encounter between customers and organizations to indirect feeling of customers about physical environment and intangible encounter between customers and invisible services and interactive system [2]. The concept of customer satisfaction was put forward by Cardozo in the marketing field in 1965, and scholars around the world started to study it since then.Hu Daohua (2011) pointed out that low customer satisfaction led to customers' complaint [3]. Bian Huangze (2012) believed that satisfaction arose from customers' consumption process, decided customers' loyalty and repurchase intention, and had something to do with customers' expectation and post factum [4]. Yang Wenchao (2013) put forward that the degree of coincidence between the purchased products or services and customers' expectations decided customer satisfaction [5]. $\mathrm{Xu}$ Zhengchuan et al. (2013) insisted that customer satisfaction was the customers' tolerance about the difference between the reality and expectations. If the difference is tolerable, it indicates that the customer is satisfied. Otherwise, the customer is dissatisfied [6].

Literature research shows that there are discussions on express service and customer satisfaction all around the 
world, but few of the discussions are on customer satisfaction from the perspective of service encounter, let alone on satisfaction evaluation. By discussing the encounter factors influencing customer satisfaction with express service and evaluating the satisfaction degree, we can know the influence factors of customer satisfaction better, and it is helpful to guide express enterprises to provide customeroriented express service according to market needs and optimize the existing express services. Besides, it is also helpful for express enterprises to improve their service quality, meet customers' needs, rapidly and greatly improve customer satisfaction, and obtain competitive edge by constructing evaluation indicators of satisfaction with express service encounter. Therefore, this paper is of practical significance to research on satisfaction with service encounter of express enterprises and the evaluation thereof.

\section{Building OF Evaluation MOdEl OF Customer SATISFACTION WITH EXPRESS SERVICE ENCOUNTER}

\section{A. Dimensional Analysis of Express Service Encounter}

By referring to the existing triad service encounter model and extension and interaction model, the following three key contact points were selected for evaluation of customer satisfaction, namely personnel, flow and cargo. Express service encounter mainly occurs between courier and customers, and between cargo and customers. Courier, who directly encounters with customers, will directly influence customers' satisfaction by service attitude and business operation. Besides, the following factors and links all have an effect on customer satisfaction, including whether the service contents meet customer needs; whether enterprises can respond rapidly after customers confirm orders; whether enterprises charge fees rationally; whether the service platform is simple and user-friendly for customers to place order, search information and point out problems; whether enterprises can handle customer complaint efficiently; and so on. Hence, this paper is intended to evaluate and analyze customer satisfaction from the three dimensions of staff encounter, process encounter and cargo encounter based on the analysis of key service encounter points in the process of express service.

\section{B. Evaluation Indexes of Express Service Encounter}

Based on the summarization of the theories on the concept, current situation, measurement dimension and relevant models of service encounter, it is planned to select indicators for evaluating customer satisfaction with express service encounter from the following three aspects, namely staff encounter, process encounter and cargo encounter. Considering there are few researches on customer satisfaction with service encounter of express enterprises, we have referred to the measurement indicators of relevant researches on customer satisfaction while adhering to the theory of service encounter and the theory of customer satisfaction to adjust and modify the indicators properly, and worked out the evaluation indicators of customer satisfaction with service encounter of express enterprises, as shown in Table I.
TABLE I. EVALUATION INDICATORS OF CUSTOMER SATISFACTION WITH EXPRESS SERVICE ENCOUNTER

\begin{tabular}{|c|c|c|}
\hline $\begin{array}{l}\text { Primary } \\
\text { Indicator }\end{array}$ & $\begin{array}{l}\text { Secondary } \\
\text { Indicator }\end{array}$ & $3^{\text {rd }}$ Grade Indicator \\
\hline \multirow{14}{*}{$\begin{array}{l}\text { Customer } \\
\text { satisfaction } \\
\text { with } \\
\text { service } \\
\text { encounter } \\
\text { of express } \\
\text { enterprises } \\
\text { (A) }\end{array}$} & \multirow{4}{*}{$\begin{array}{l}\text { Process } \\
\text { encounter } \\
\left(\mathrm{B}_{1}\right)\end{array}$} & Scope of Business $\left(\mathrm{C}_{1}\right)$ \\
\hline & & Order response capability $\left(\mathrm{C}_{2}\right)$ \\
\hline & & Service platform efficiency $\left(\mathrm{C}_{3}\right)$ \\
\hline & & Complaint handling efficiency $\left(\mathrm{C}_{4}\right)$ \\
\hline & \multirow{5}{*}{$\begin{array}{l}\text { Cargo } \\
\text { encounter } \\
\left(\mathrm{B}_{2}\right)\end{array}$} & Timely delivery of cargo $\left(\mathrm{C}_{5}\right)$ \\
\hline & & Accurate delivery of cargo $\left(\mathrm{C}_{6}\right)$ \\
\hline & & Cargo in perfect condition $\left(\mathrm{C}_{7}\right)$ \\
\hline & & Package in perfect condition $\left(\mathrm{C}_{8}\right)$ \\
\hline & & Cargo information feedback $\left(\mathrm{C}_{9}\right)$ \\
\hline & \multirow{5}{*}{$\begin{array}{l}\text { Staff } \\
\text { encounter } \\
\left(\mathrm{B}_{3}\right)\end{array}$} & Image of courier $\left(\mathrm{C}_{10}\right)$ \\
\hline & & Attitude of courier $\left(\mathrm{C}_{11}\right)$ \\
\hline & & $\begin{array}{l}\text { Business operation of service personnel } \\
\left(\mathrm{C}_{12}\right)\end{array}$ \\
\hline & & Customer service responsiveness $\left(\mathrm{C}_{13}\right)$ \\
\hline & & $\begin{array}{l}\text { Communicational ability of customer } \\
\text { service staff }\left(\mathrm{C}_{14}\right)\end{array}$ \\
\hline
\end{tabular}

\section{Determination of Indicator Weight of Express Service} Encounter

The computing methods of indicator weight include analytical hierarchy process, expert scoring method, simple correlation function method, factor analysis method, and so on. To ensure scientific and valid weight coefficients are determined, and avoid disturbance of subjectivity and arbitrariness, the factor analysis method is adopted to determine indicator weight in this paper. On this basis, the fuzzy synthetic evaluation method is adopted to calculate the score of each evaluation indicator of customer satisfaction with service encounter of express enterprises and the sum of scores.

\section{THE EMPIRICAL RESEARCH}

For purpose of this paper, the Likert 5-grade scale is adopted to design five options for evaluating customer satisfaction of respondents with express service encounter, namely "not satisfied at all" (1score), "not satisfied" (2 scores), "average” (3 scores”), "fairly satisfied” (4 scores), and "very satisfied" (5scores); and design five options for evaluating the degree of importance of the indicators of express service encounter, namely "not important at all" (1 score), "not important" (2 scores), "average” (3 scores), "fairly important” (4 scores) and "very important” (5 scores). After all the questions of the questionnaire have been subject to review and examination by expert one by one, and adjusted according to expert opinions, the questionnaires are handed out, and data analysis is made.

\section{A. Analysis of Reliability and Validity of Questionnaire}

\section{1) Analysis of Validity}

According to the analysis result obtained with SPSS software, the KMO value is 0.881, larger than 0.5; the level of significance of Bartlett's test of sphericity is 0.000 , lower than 0.001 , indicating that the requirements for the level of 
significance are met with. The foregoing data suggests that this questionnaire can be used for factor analysis. The principal component analysis method is adopted to extract factors, taking factors of which the characteristic value is larger than or equal to 1 as the interception standard to obtain the total factor variance explained. It is found that there are 3 factors of which the characteristic value is larger than 1 , and the cumulative sharing rate of the 3 factors reaches $68.432 \%$ (higher than the minimum margin of 50\%),indicating that the 3 factors are adequate to explain and represent the sample data.

The 3 factors are put under orthogonal rotation to obtain a factor loading matrix, and it is found that the load factor of all the variables is larger 0.5 , indicating the convergent validity is high. Meanwhile, the 3 factors are extracted according to the factor load value, and named staff encounter factor, process encounter factor, and cargo encounter factor respectively. This suggests that the dimensions of staff encounter, process encounter and cargo encounter selected in this paper for evaluating customer satisfaction in accordance with the theory of service encounter are rational.

2) Analysis of Reliability

Reliability test over the questionnaire as a whole and over the factors shows that the Cronbach $\alpha$ value of the whole questionnaire is 0.917 , and that of each factor are $0.850,0.908$, and 0.829 respectively, as shown in Table II. On the whole, the reliability of the questionnaire reaches the requirements, and the questionnaire is of the required reliability.

TABLE II. RELIABILITY STATISTICS OF FACTORS

\begin{tabular}{|c|c|c|}
\hline Factor & Cronbach's Alpha & Number of item \\
\hline Staff encounter factor & 0.850 & 4 \\
\hline Process encounter factor & 0.908 & 5 \\
\hline Cargo encounter factor & 0.829 & 5 \\
\hline
\end{tabular}

\section{B. Analysis of Calculation and Result of Customer Satisfaction}

\section{1) Determination of Indicator Weight}

a) Determination of Secondary Indicator Weight

The weights of the secondary indicator layer relative to the primary indicator layer can be determined according to the rate of contribution $a_{i}$ of each indicator to the primary target layer [7]. Factor contribution rate refers to the proportion of information contained in each factor to the total information in factor analysis. The sample variance explained of the 3 factors is the factor contribution rates of the 3 factors, which are $48.88 \%, 11.18 \%$ and $8.37 \%$ respectively. After this, the contribution rates of the main factors are normalized, and the weight values of the main factors relative to the primary indicators are calculated. The calculations show that the weights of cargo encounter, process encounter and staff encounter are 0.71, 0.16 and 0.13 respectively, indicating that cargo encounter is the most important influence factor of customer satisfaction, and enterprises should focus on the optimization of the process of cargo encounter to improve customer satisfaction with service encounter of express enterprise.

TABLE III. WEIGHTS OF SECONDARY INDICATORS

\begin{tabular}{|c|c|c|}
\hline Influence factor & Contribution rate & Weight \\
\hline Cargo encounter & $48.88 \%$ & 0.71 \\
\hline Staff encounter & $11.18 \%$ & 0.16 \\
\hline Process encounter & $8.37 \%$ & 0.13 \\
\hline Total & & 1 \\
\hline
\end{tabular}

b) Determination of $3^{\text {rd }}$ Grade Indicators

The weights of $3^{\text {rd }}$ grade indicators can be calculated with the communality percent method. The communality of an indicator means the degree that the indicator can be explained. Suppose the factor loading matrix is A, and the quadratic sum of indicators in the row is the communality of the indicators (namely variable variance), denoted by $h_{i}^{2}$

$$
h_{i}^{2}=\sum_{j=1}^{k} a_{i j}^{2}(i=1,2, \cdots, p)
$$

$a_{\mathrm{ij}}$ stands for factor load, namely the load of the variable on the factor; $\mathrm{p}$ stands for the count of original variables; $\mathrm{K}$ stands for the count of common factors. The computational formula of the weight $w_{i}$ of the indicator is:

$$
w_{i}=\frac{h_{i}^{2}}{\sum h_{i}^{2}}
$$

The results of calculation of the weights of the $3^{\text {rd }}$ grade indicators relative to the secondary indicators obtained with the communality percent method are as shown in TableIII. According to the table, with respect to process encounter, the order of the indicators influencing customer satisfaction with express enterprises from high to low is service platform efficiency, complaint handling efficiency, order response capability, and scope of business; with respect to cargo encounter, the order of the indicators influencing customer satisfaction with express enterprises from high to low is timely delivery of cargo, cargo in perfect condition, cargo information feedback, accurate delivery of cargo, and package in perfect condition; with respect to staff encounter , the order of the indicators influencing customer satisfaction with express enterprises from high to low is attitude of courier, business operation of courier, customer service responsiveness , and communication ability of customer service staff. To improve customer satisfaction with service encounter, express enterprises can focus on the construction of service platform, improvement of timeliness of cargo delivery, and training of service attitude of courier.

\section{2) Calculation of Customer Satisfaction}

For purpose of this paper, the fuzzy synthetic evaluation method is adopted to calculate the score of each evaluation indicator of customer satisfaction with service encounter of express enterprises and the sum of scores.

a) Calculation according to $3^{\text {rd }}$ Grade Indicators 
The scores of the $3^{\text {rd }}$ grade indicators of customer satisfaction are calculated with the method of weighted mean, of which the formula is:

$$
\begin{gathered}
\mathrm{TS}=\bar{W} \mathrm{RV} \\
\bar{W}=\left(W_{1}, W_{2}, \cdots, W_{n}\right), \quad \sum_{i=1}^{n} w_{i}=1 \\
\mathrm{~V}_{\mathrm{ij}}=(1,2,3,4,5)^{T}
\end{gathered}
$$

$r_{i j}$ stands for a matrix constructed by the row vector of $r_{i}$ $V_{i j}$ stands for the score of satisfaction. The satisfaction memberships and satisfaction scores of the 3rd grade indicators are as shown in the table below:

TABLE IV.

THREE INDICATORS OF SECONDARY INDICATORS WEIGHT VALUE

\begin{tabular}{|c|c|c|}
\hline Indicator & Communalities & Weight \\
\hline Scope of Business & 0.55 & 0.19 \\
\hline Order response capability & 0.676 & 0.24 \\
\hline Service platform efficiency & 0.814 & 0.29 \\
\hline Complaint handling & 0.81 & 0.28 \\
\hline Timely delivery of cargo & 0.821 & 0.23 \\
\hline Accurate delivery of cargo & 0.719 & 0.20 \\
\hline Cargo in perfect condition & 0.802 & 0.22 \\
\hline Package in perfect condition & 0.559 & 0.15 \\
\hline Cargo information feedback & 0.745 & 0.20 \\
\hline Image of courier & 0.597 & 0.19 \\
\hline Attitude of courier & 0.736 & 0.24 \\
\hline $\begin{array}{c}\text { Business operation of service } \\
\text { personnel }\end{array}$ & 0.694 & 0.23 \\
\hline $\begin{array}{c}\text { Customer service } \\
\text { responsiveness }\end{array}$ & 0.581 & 0.19 \\
\hline $\begin{array}{c}\text { Communicational of customer } \\
\text { service staff }\end{array}$ & 0.477 & 0.15 \\
\hline
\end{tabular}

b) Calculation of Customer Satisfaction according to Secondary Indicators

The calculation of customer satisfaction according to secondary indicators is similar to that according to $3^{\text {rd }}$ grade indicators. The calculations show that the satisfaction scores of the secondary indicators (process encounter, cargo encounter and staff encounter) are 3.65, 3.75 and 3.81 respectively, as shown in the tablebelow:

\begin{tabular}{|c|c|c|c|c|c|c|c|}
\hline \multirow[b]{2}{*}{ Indicator } & \multirow[b]{2}{*}{ Weight } & \multicolumn{5}{|c|}{ Sets of fuzzy evaluation } & \multirow[b]{2}{*}{ Score } \\
\hline & & 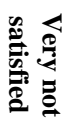 & 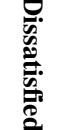 & $\begin{array}{ll}\text { of } & \overline{1} \\
\text { os } & \mathbf{m}\end{array}$ & 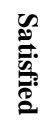 & 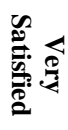 & \\
\hline Cargo & 0.71 & 0.00 & 0.03 & 0.3 & 0.3 & 0.21 & 3.75 \\
\hline
\end{tabular}

TABLE V.SECONDARY INDEXES SETS OF FUZZY EVALUATION AND EVALUATION SCORE

\begin{tabular}{|c|c|c|c|c|c|c|c|}
\hline encounter & & 2 & 49 & $\begin{array}{c}34 \\
6\end{array}$ & $\begin{array}{c}98 \\
7\end{array}$ & 66 & \\
\hline $\begin{array}{c}\text { Staff } \\
\text { encounter }\end{array}$ & 0.16 & $\begin{array}{c}0.00 \\
24\end{array}$ & $\begin{array}{c}0.03 \\
7\end{array}$ & $\begin{array}{c}0.3 \\
47 \\
8\end{array}$ & $\begin{array}{c}0.3 \\
43\end{array}$ & $\begin{array}{c}0.26 \\
52\end{array}$ & 3.81 \\
\hline $\begin{array}{c}\text { Process } \\
\text { encounter }\end{array}$ & 0.13 & $\begin{array}{c}0.00 \\
19\end{array}$ & $\begin{array}{c}0.04 \\
46\end{array}$ & $\begin{array}{c}0.3 \\
71 \\
1\end{array}$ & $\begin{array}{c}0.3 \\
94\end{array}$ & $\begin{array}{c}0.17 \\
46\end{array}$ & 3.65 \\
\hline
\end{tabular}

The calculations of satisfaction scores of the $3^{\text {rd }}$ grade indicators show that most scores range from 3 and 4, and the three indicators of which the satisfaction scores are highest are cargo information feedback, communication ability of customer service staff, and customer service responsiveness, of which the scores are 4.17, 4.03 and 4.01 respectively; the three indicators of which the satisfaction scores are lowest are timeliness of cargo delivery, order response efficiency, and service attitude of courier, of which the scores are 3.31,3.41 and 3.47 respectively. This suggests that express enterprises perform well in respect of cargo information feedback and customer service, and have certain problems in respect of timeliness of cargo delivery, order response efficiency and service attitude of courier, which needs to be improved.

\section{Analysis of Application of Customer Satisfaction with Express Service Encounter}

The quarter chart method refers to a method of qualitative evaluation and determination of satisfaction by estimating the importance of indicators. The quarter chart method is useful to figure out the key influence factors of customer satisfaction visually.

Figure 1 shows that indexes of advantage zoneinclude cargo intact, accurate delivery of goods,non-destructive and suitable packing,and the information feedback of goods. These indexesexplain that in the process of express service, intact, accurate delivery of goods,packaging of goods for non-destructive and feedback meet the customer requirements relatively; Indexes in the repair zone are the timely delivery of the goods, indicating the higher weights, but the level of satisfaction relatively not so high; opportunity zone include the response capacity to the order, express personnel services and the wide range of businesses. The importance of Indexes in the region are relatively less, satisfaction scores were relatively low; maintenance including complaint-handling efficiency, courieroperations, convenience of service platform and the image of delivery staff, customer service responsiveness and customer communication skills. These indicators are of low weight, and relatively high satisfaction scores.

\section{CONCLUSION}

The service of express business encounter customer satisfaction research to guide the delivery of enterprise customer-oriented, it can better help the courier company to improve quality of service. Improving customer satisfaction quickly and effectively, in order to gain the competitive advantages. Therefore, the research on the satisfaction degree and the evaluation of express enterprise service encounter has practical significance. After a thorough analysis, we can reach the following conclusion. 
First of all, the rationality of the index is verified by factor analysis, and determine the weight of each evaluation index. It is found that the process of goods encounter plays an important role in customer satisfaction. To enhance service satisfaction and customer satisfaction of express enterprises, the enterprises need to focus on improving the process of goods contact, In addition, to improve service encounter of customer satisfaction, it can focus on strengthening the construction of service platform, and improve the timeliness of goods delivery, and strengthen the service attitude of express personnel training

Secondly, the fuzzy comprehensive evaluation method, to calculate the indicators of satisfaction score. Found that express company feedback information of the goods and customer service staff to service do better, however, there are some problems in timely delivery of the goods, order response speed and courier service attitude.

Finally, according to the evaluation index weight and satisfaction score of four chart analysis. It is found that most of the evaluation indicators are in the dominant and maintenance areas, it also can be optimized on the basis of maintenance. Only one indicator is in the timeliness of goods in the repair area, the study also demonstrated express enterprises need to increase the timely delivery of goods attention, Measures are taken to optimize the service of view on how to improve customer satisfaction study conducted more integrated.

\section{REFERENCES}

[1] Batero A.J. "Using Service Incidents to Identify Quality Improvement Points,” International Journal of Contemporary Hospitality Management, vol. 10, 2013, pp. 99-106.

[2] Qomack C.H. “Services Marketing,” Englewood Cliffs: NJ: 2014.

[3] Hu Daohua,Zhao Liming. "Evaluation of tourists' perception based on tourists' feedback,” Journal of Xiangtan University,vol. 35, 2011.

[4] Bian Huangze,Xiang Ying. "Empirical study on customer satisfaction of supermarket shopping environment,”Consumer Economics,vol. 28, 2012, pp. 66-69.

[5] Yang Wenchao. "Service quality, customer satisfaction and customer loyalty research,” Economic Tribune, vol. 11, 2013, pp. 124-129.

[6] Xu Zhengchuan,Pan Yu,Liang June,Lv Tingjie. "Context-awareness based on customer satisfaction model journey planning system,” China communications, vol. 6, 2013, pp. 166-173.

[7] Zhao Jianjun,Huang Runqiu. "Weights of Slope Stability Evaluation Indexes Based on Factor Analysis Method,”Journal of Southwest Jiaotong University, vol. 410, 2015, pp.325-330.

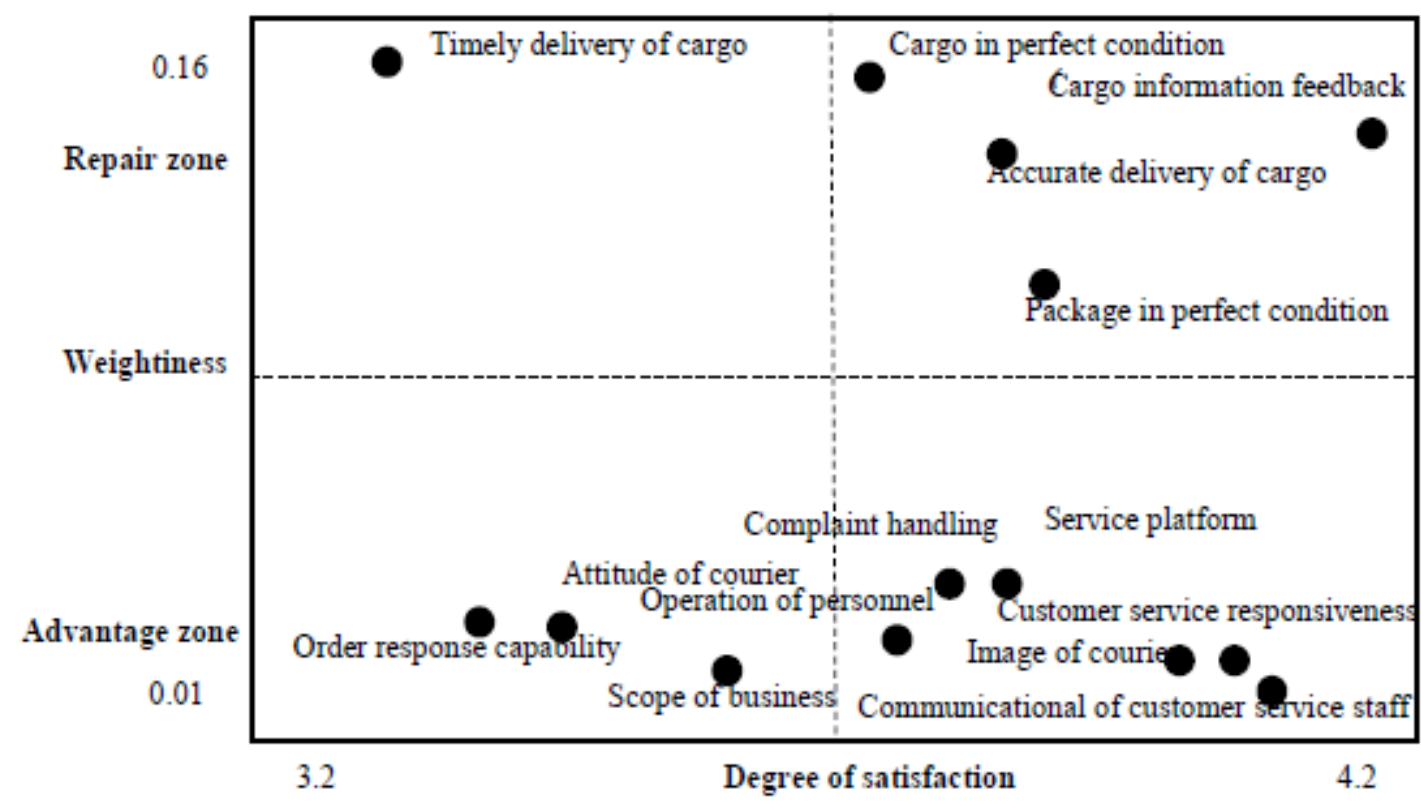

Opportunity zone

Figure 1. Customer satisfaction index -- Importance of four points figure analysis 